\title{
Hemophilia A in Brazil - epidemiology and treatment developments
}

This article was published in the following Dove Press journal:

Journal of Blood Medicine

23 September 2014

Number of times this article has been viewed

\author{
Adriana Aparecida Ferreira' \\ Isabel Cristina Gonçalves \\ Leite $^{2}$ \\ Maria Teresa Bustamante- \\ Teixeira $^{2}$ \\ Maximiliano Ribeiro \\ Guerra $^{2}$ \\ 'Foundation and Center for \\ Hematology and Hemotherapy \\ of Minas Gerais (Hemominas), \\ ${ }^{2}$ Department of Collective Health, \\ Federal University of Juiz de Fora, \\ Juiz de Fora, Minas Gerais, Brazil
}

Correspondence: Adriana Aparecida Ferreira Rua Barão de Cataguases, s/n, Juiz de Fora, Minas Gerais, CEP 360I5-370, Brasil Email adriana.hemato@gmail.com

\begin{abstract}
Hemophilia A is an inherited disorder characterized by deficiency of coagulation factor VIII, which predisposes patients to bleeding events. Treatment is based on replacement of the deficient factor, in a therapeutic or prophylactic manner. Brazil is the country with the third largest population of people with hemophilia, for which the public health system provides free comprehensive care. Maintaining an updated registry of patients, documenting the prevalence of complications, and assessing the effectiveness of resource use are indispensable elements in the design of a well-coordinated national program. According to sociodemographic, clinical, and laboratory data collected by the computerized Brazilian system on coagulopathies, in June 2013, there were 9,122 registered patients with hemophilia A in Brazil, of which 36.1\% had a severe form of the disease. Clotting factor inhibitors were present in $7.5 \%$, but $25.7 \%$ of records did not provide this type of data. Around $70 \%$ of the patients belonged to the economically active population, being between 15 and 59 years old. Infection by the human immunodeficiency virus was present in $23.4 \%$ of the patients tested and infection by hepatitis $\mathrm{C}$ virus antibodies in $59.3 \%$. Infection by the hepatitis B virus and human T-lymphotropic virus was also reported. The high percentage of incomplete records regarding serological data shows the fragility of the information system to date. There was also no information available on the prevalence of permanent or disabling joint damage. Although few hemophiliacs receive adequate care in developing countries, and despite Brazil exhibiting great social inequalities, the Ministry of Health has made significant advances in the treatment of hemophilia A. The gradual increase in importation of factor VIII concentrate enabled the implementation of primary and secondary modalities of prophylaxis, in addition to the induction of immune tolerance. There are also plans to set up a factory in the country, to ensure Brazilian self-sufficiency in the production of blood products.
\end{abstract}

Keywords: cryoprecipitate, factor VIII, prophylaxis, comprehensive health care, health information system

\section{Introduction}

Hemophilia A is a bleeding disorder resulting from the inherited deficiency of coagulation factor VIII (FVIII), which is transmitted recessively and linked to the $\mathrm{X}$ chromosome. ${ }^{1}$ Patients tend to have recurrent bleeding of varying severity, which occurs spontaneously or posttraumatically in any organ or tissue. ${ }^{2}$ Over $90 \%$ of the hemorrhagic events involve hemarthrosis, intra-articular bleeding that begins to occur in the first years of life. When recurrent and untreated, or inadequately treated, hemarthrosis results in permanent damage to articular cartilage, leading to deforming and crippling arthropathy even in the second decade of life. ${ }^{3}$

The treatment of hemophilia A in Brazil is based on the replacement of the deficient factor by intravenous infusion of plasma-derived or recombinant FVIII concentrates, 
high-cost medications whose acquisition is the responsibility of the Ministry of Health. ${ }^{4}$

Brazil encompasses a territory of $8,511,965 \mathrm{~km}^{2}$, divided into 26 states and a federal district. These 27 federal units comprise five geographic regions (Figure 1), in which ethnic and cultural diversity and socioeconomic inequality are quite pronounced (Table 1). ${ }^{5}$

Of the 193,976,530 inhabitants, $8.7 \%$ are illiterate and $43 \%$ work in an informal way. ${ }^{6}$ With a gross domestic product per capita of US $\$ 11,530$, the country exhibits great social inequality. The Gini coefficient for household income was 0.547 in 2009, according to the World Bank. ${ }^{7}$

The Brazilian health system is public, funded by federal, state, and municipal budgets. It guarantees everyone universal and full access to activities targeting health promotion, protection, and recovery. It is estimated that over $80 \%$ of the population relies exclusively on the Unified Health System (Sistema Único de Saúde [SUS]) for these services. ${ }^{8}$ Through the Care Program for People with Hemophilia and Other Inherited Bleeding Disorders, the SUS is responsible for the assistance of hemophilia patients. The main activities of the program include the acquisition of FVIII concentrates and their distribution to the 183 Hemophilia Treatment Centers (HTCs) around the country. ${ }^{4}$

According to the World Federation of Hemophilia, Brazil has, in absolute numbers, the third largest population of patients with hemophilia, smaller only than that in the United
States and in the People's Republic of China. ${ }^{9}$ The Brazilian government has been striving to increase the supply of quality blood products to sufficient quantities to ensure proper treatment of these individuals. However, regional disparities pose a major problem when planning a national coverage program for the treatment of hemophilia. ${ }^{10}$

\section{Short history of hemophilia in Brazil}

In Brazil, the process of industrialization that took place in the 1960s and the subsequent urbanization led to the concentration of large numbers of people in the larger cities. Changes in the industrial landscape and in the transportation system contributed as determining factors in the increasing number of workplace and traffic accidents, generating a greater demand for blood products. This spurred a growing class of paid blood donors, mostly coming from marginalized populations of the major urban centers, who relied on the practice of selling blood to private blood banks to improve their purchasing power. ${ }^{11}$ These private blood banks were also responsible for providing cryoprecipitate and fresh frozen plasma for the treatment of hemophilia patients, for a number of years. ${ }^{10}$

Speculation in blood and commercialization of contaminated blood components led the Brazilian government to approve the basic guidelines of the National Program for Blood and Blood Products (Pró-Sangue) in 1980, whose goals

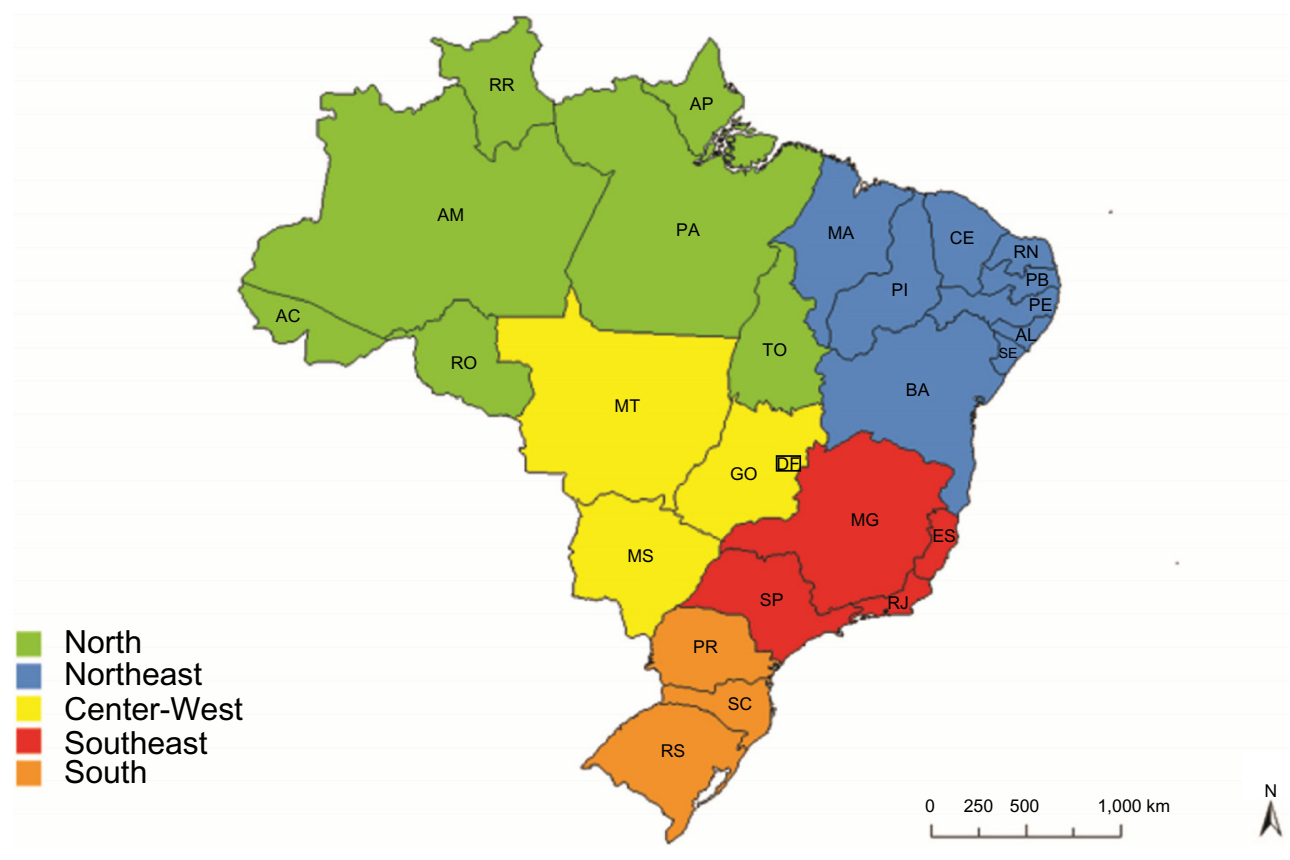

Figure I Political map of Brazil, delineated by state, and grouped by geographic regions.

Abbreviations: AC, Acre; AL, Alagoas; AM, Amazonas; AP, Amapá; BA, Bahia; CE, Ceará; DF, Federal District; ES, Espírito Santo; GO, Goiás; MA, Maranhão; MG, Minas Gerais; MS, Grosso do Sul; MT, Mato Grosso; PA, Pará; PB, Paraíba; PE, Pernambuco; PI, Piauí; PR, Paraná; RJ, Rio de Janeiro; RN, Rio Grande do Norte; RO, Rondônia; RR, Roraima; RS, Rio Grande do Sul; SC, Santa Catarina; SE, Sergipe; SP, São Paulo; TO, Tocantins. 
Table I Socioeconomic inequalities: regional averages and their ranges at the state level, Brazil, 2010

\begin{tabular}{|c|c|c|c|}
\hline $\begin{array}{l}\text { Geographic } \\
\text { region }\end{array}$ & $\begin{array}{l}\text { Illiterates } \\
\text { (age }>\text { I5 years) }\end{array}$ & $\begin{array}{l}\text { GDP per } \\
\text { capita (USD) }\end{array}$ & $\begin{array}{l}\text { Low-income } \\
\text { population } \\
\text { (<150 USD/ } \\
\text { month) }\end{array}$ \\
\hline North & $\begin{array}{l}11.1 \% \\
(8.1 \%-16.6 \%)\end{array}$ & $\begin{array}{l}7,471 \\
(6,040-10,093)\end{array}$ & $\begin{array}{l}52.8 \% \\
(35.4 \%-57.6 \%)\end{array}$ \\
\hline Northeast & $\begin{array}{l}18.5 \% \\
(16.2 \%-23.6 \%)\end{array}$ & $\begin{array}{l}5,623 \\
(4,048-6,807)\end{array}$ & $\begin{array}{l}56.1 \% \\
(48.9 \%-64.7 \%)\end{array}$ \\
\hline Center-West & $\begin{array}{l}7.0 \% \\
(3.6 \%-8.4 \%)\end{array}$ & $\begin{array}{l}14,670 \\
(9,560-34,309)\end{array}$ & $\begin{array}{l}25.9 \% \\
(18.3 \%-29.5 \%)\end{array}$ \\
\hline Southeast & $\begin{array}{l}5.3 \% \\
(4.2 \%-8.1 \%)\end{array}$ & $\begin{array}{l}15,284 \\
(10,547-17,785)\end{array}$ & $\begin{array}{l}23.7 \% \\
(19.4 \%-30.3 \%)\end{array}$ \\
\hline South & $\begin{array}{l}5.0 \% \\
(4.0 \%-6.1 \%)\end{array}$ & $\begin{array}{l}13,365 \\
(12,237-14,354)\end{array}$ & $\begin{array}{l}19.2 \% \\
(13.9 \%-21.3 \%)\end{array}$ \\
\hline
\end{tabular}

Note: Data from Brazilian Institute of Geography and Statistics - IBGE. Directorate of Surveys, Department of Population and Social Indicators. Sintese de Indicadores Sociais 2013. Uma análise das Condições de Vida da População Brasileira. [A syntheses of social indicators 2013]. Brazil: Brazilian Institute of Geography and Statistics; $2013{ }^{6}$ Abbreviations: GDP, gross domestic product; USD, US dollars.

were to organize a network of institutions responsible for the supply and distribution of blood and derivatives, adopt voluntary blood donation in a systematic manner, and regulate the production of blood products. The program established blood centers in the state capitals as model services in the control, processing, and distribution of blood, in addition to acting as the sites for staff training, research, diagnosis, and treatment of patients with coagulopathies. ${ }^{12}$

In 1988, the Brazilian Constitution barred any form of commercialization of blood and blood products. This measure was the outcome of a campaign led by two brothers, both with hemophilia, the sociologist Herbert de Souza and the cartoonist Henrique de Souza, known as Henfil, both infected by the human immunodeficiency virus (HIV) through infusions of cryoprecipitate. The campaign attempted to mobilize society with the motto "Save the blood of the Brazilian people" since at that time, over $60 \%$ of patients with hemophilia were infected by HIV and hepatitis $\mathrm{C}$ virus.

There was a small plasma fractionation center in the state of Rio de Janeiro that produced FVIII concentrate in amounts that supplied $10 \%$ of the country's demand. Most of the patients with hemophilia A were treated with cryoprecipitate, while a few others received FVIII concentrates imported separately by some hospitals or by state governments. ${ }^{13}$

In the 1990s, the SUS began importing FVIII concentrates at a ratio of 10,000 IU per hemophilia A patient per year, while the World Federation of Hemophilia advocated that at least 20,000 IU, corresponding to 1 IU per capita/ year, would be needed to maintain the optimum survival of patients. ${ }^{14}$ At that time, the imports occurred irregularly, and the distribution criteria were not well defined. ${ }^{10}$ In 1994, the
Ministry of Health decided to establish a national program for the treatment of hemophilia, planning the annual purchase of 20,000 IU of FVIII concentrate per patient and organizing the distribution of blood products. Each coordinating blood center was designated to stock and distribute FVIII concentrates to the HTCs, where patients receive the drug for free, even if served by private health plans. ${ }^{13}$

Given the lack of uniformity in treatment, a national hemophilia committee was created, linked to the National Health Surveillance Agency (Agência Nacional de Vigilância Sanitária), in 1998. Its first action was to send a questionnaire to all blood centers to determine the number of patients with hemophilia registered in each state, the clinical and laboratory profiles of these patients, and the number of health professionals and laboratory facilities available. ${ }^{15}$ With the analysis of the data collected in the first investigation, a prototype national database was formed, and a diagnostic laboratory network was organized.

In 2001, imports of FVIII concentrate by the Ministry of Health reached 30,000 IU per registered patient. ${ }^{10}$ Given the availability of processed blood products and considering the ongoing risk of transmission of infectious diseases, the use of cryoprecipitate was banned as a treatment for hemophilia in Brazil in 2002. ${ }^{16}$

\section{The "Hemovida Web Coagulopathies" information system}

Maintaining an updated registry of hemophilia patients is essential for documenting the epidemiology and natural history of the disease, planning research, managing treatment programs, and evaluating the effective use of resources, especially when a substantial amount of public resources are spent on treating a low-prevalence disease., ${ }^{9,17}$ Based on this premise, one of the first steps by the Brazilian government was to develop a national registry of patients with hemophilia. ${ }^{13}$

Until December of 2008, this record was compiled from worksheets mailed to the blood centers, raising all sorts of problems, such as incomplete data delivery, difficulty in updating the data, typographical errors, and duplicate records. In January 2009, the Ministry of Health implemented the "Hemovida Web Coagulopathies" computerized system, seeking to regulate the information criteria, to improve care to patients with coagulopathies. Increasing the reliability of individual data, the system could allow adjustments in patient care policy and more effective expenditures. ${ }^{4}$ The HTCs are responsible for maintaining constant updates on 
the prevalence of inherited bleeding disorders, the clinical data of patients, and the dispensing of coagulation factors. Despite having created excellent data update conditions, the computerized database still appears weak regarding its data feeds, which is perceptible when the quality of the resulting epidemiological information is analyzed.

\section{Epidemiology of hemophilia A in Brazil}

It is estimated that the prevalence of hemophilia A varies from $0.5-2$ per 10,000 male births, being lower in low-income countries. ${ }^{1,18}$ It is believed that the difficulty of diagnosis, inaccurate record-keeping practices, and the unavailability of treatment, which eventually leads to death, even at an early age, contribute to the prevalence being lower in places with limited resources. While the average prevalence of hemophilia A in developed countries was $1.28 \pm 0.6$ per 10,000 men in 2006 , in the poorest countries it was $0.66 \pm 0.48$. In recent years, an increasing trend in prevalence in developed countries, such as Canada, The Netherlands, and the UK, has also been described. ${ }^{19}$

In 2012, the total number of patients (including men, women, and babies) with hemophilia A registered in Brazil climbed to $9,122(0.95 / 10,000), 32.5 \%$ higher than that recorded in $2007(0.74 / 10,000)$. The prevalence ranged from $0.36 / 10,000$ men in the state of Roraima to $1.79 / 10,000$ men in the Federal District, ${ }^{20,21}$ there being a positive correlation between the number of recorded hemophilia cases and the average monthly household income per capita in the states ( $r=0.47, P=0.013)$ and in the regions $(r=0.879, P=0.021)$ of Brazil. The prevalence of hemophilia A, by Brazilian geographic region, is shown in Table 2.

Of the 9,122 patients with hemophilia A, 98.2\% were male (including children and adults) and 161 (1.8\%) were female (including children and adults), diagnosed with hemophilia or as symptomatic carriers. Almost seventy percent (69.7\%) of the patients were between 15 and 59 years of age, constituting the economically active population. ${ }^{21}$ Table 3 shows the age distribution of patients with hemophilia A..$^{21,22}$

The severe form of hemophilia A (residual FVIII activity $<1 \%$ ) was reported in $36.1 \%$ of the cases; a further $24.2 \%$ referred to the moderate form (with activity between $1 \%$ and $5 \%$ ), and the remaining $25.3 \%$ were related to the mild form of the disease (FVIII activity between 5\% and 30\%). It is important to note that in a significant proportion of the records (14.4\%), the severity of hemophilia was not reported in the Hemovida Web Coagulopathies system. ${ }^{1,21}$

The presence of inhibitors, alloantibodies against infused FVIII, is the most feared complication related to the treatment of hemophilia A. ${ }^{23}$ Patients affected by inhibitors do not adequately respond to normal treatment and require FVIII concentrates at higher doses, or alternative medicines, with even higher costs. ${ }^{24}$ Among patients with hemophilia A who were tested $(6,835), 7.5 \%$ were found to have already presented at least one positive inhibitor test, and in $50.9 \%$ of these cases, high-response inhibitors (ie, with a titration greater than 5 Bethesda units per milliliter). However, ${ }^{25}$ it has been reported that $25.1 \%$ of patients either had not been tested or did not have their data registered. In three Brazilian states, Amapá, Mato Grosso do Sul, and Sergipe, more than 90\% of patients had no records regarding the test for coagulation factor inhibitors (Table 4). ${ }^{21}$

In $2007,4.5 \%$ of the patients with hemophilia A presented a positive serology for acquired human immunodeficiency virus (anti-HIV), and 30.1\% either had not been tested or their results had not been reported to the national registry. ${ }^{20}$ With the implementation of the computerized system, the lack of information on serology status or of performance of the test reached a level of $82.8 \%$ among patients in 2012. It is assumed that this situation is due to failure to update the Hemovida Web Coagulopathies database by the HTCs, demonstrating once again, the fragility of the system. The possibility that

Table 2 Prevalence of hemophilia $A$ in the male population and average monthly household income per capita, by geographic region, Brazil, 2012

\begin{tabular}{lllll}
\hline $\begin{array}{l}\text { Geographic } \\
\text { region }\end{array}$ & $\begin{array}{l}\text { Male resident } \\
\text { population }\end{array}$ & $\begin{array}{l}\text { Hemophilia A } \\
\text { patients }\end{array}$ & $\begin{array}{l}\text { Prevalence } \\
\text { (per I0,000 men) }\end{array}$ & $\begin{array}{l}\text { Monthly average household income, } \\
\text { per capita, in USD, 20 I0 }\end{array}$ \\
\hline Southeast & $39,829,102$ & 3,829 & 0.961 & 527.16 \\
Northeast & $26,429,312$ & 2,431 & 0.919 & 256.29 \\
South & $13,646,949$ & 1,390 & 1.018 & 514.06 \\
North & $8,335,564$ & 749 & 0.898 & 276.12 \\
Center-West & $7,237,503$ & 723 & 0.998 & 522.53 \\
Total & $95,478,430$ & 9,122 & 0.955 & 428.62 \\
\hline
\end{tabular}

Note: Data from Ministry of Health. Health Care Secretary. Coordenação Geral de Sangue e Hemoderivados. Perfil das coagulopatias hereditárias no Brasil: 201 I-20I2. [General Coordination of Blood and Blood Products. Profile of hereditary coagulopathies in Brazil: 20II-20I2]. Brazil: Ministry of Health; 20I4. ${ }^{21}$ ibge.gov.br [homepage on the Internet]. Censo demográfico 20I0. Instituto Brasileiro de Geografia e Estatítica; 20 I0 [Census 20I0. Brazilian Institute of Geography and Statistics - IBGE]. [cited February 27, 2014].22

Abbreviation: USD, US dollars. 
Table 3 Age distribution of patients with hemophilia A, Brazil, 2012

\begin{tabular}{lll}
\hline Age group & Patients with hemophilia A & $\%$ \\
\hline$<1$ year & 0 & $0 \%$ \\
I-4 years & 463 & $5.08 \%$ \\
$5-9$ years & 826 & $9.06 \%$ \\
$10-14$ years & 1,011 & $11.08 \%$ \\
$15-19$ years & 1,131 & $12.40 \%$ \\
$20-29$ years & 2,089 & $22.90 \%$ \\
$30-39$ years & 1,611 & $17.66 \%$ \\
$40-49$ years & 972 & $10.66 \%$ \\
$50-59$ years & 558 & $6.12 \%$ \\
$60-69$ years & 254 & $2.78 \%$ \\
$70-79$ years & 102 & $1.12 \%$ \\
$\geq 80$ years & 60 & $0.66 \%$ \\
Not reported & 45 & $0.49 \%$ \\
Total & 9,122 & $100 \%$ \\
\hline
\end{tabular}

Note: Data from Ministry of Health. Health Care Secretary. Coordenação Gera de Sangue e Hemoderivados. Perfil das coagulopatias hereditárias no Brasil: 201 I-20/2. [General Coordination of Blood and Blood Products. Profile of hereditary coagulopathies in Brazil: 20II-20I2]. Brazil: Ministry of Health; 2014. ${ }^{21}$

tests were not performed due to laboratory access problems must also be considered but seems a less likely reason for the lack of information. The same occurred with respect to the serology results for hepatitis $\mathrm{B}$, hepatitis $\mathrm{C}$, and human T-lymphotropic virus, as can be seen in Table $5 .{ }^{21}$

The proportion of patients with hemophilia A who have crippling joint damage is not known, although admittedly, hemarthrosis and osteoarticular sequelae cause great negative impact on the economic productivity and health-related quality of life of these patients. ${ }^{25}$

\section{Evolution of hemophilia A treatment in Brazil}

In 2004, the Brazilian Enterprise for Blood Products and Biotechnology (HEMOBRAS) was created. Budgeted at 246 million dollars and with a catchment area of $48,000 \mathrm{~m}^{2}$, the plant was designed to process 500,000 liters of plasma per year. Despite the initial intent to produce plasma-derived medicines

Table 4 Proportion of patients with hemophilia $A$ and the presence of inhibitors, by geographic region, Brazil, 2012

\begin{tabular}{llll}
\hline Region & \multicolumn{2}{l}{ Test for inhibitors } \\
\cline { 2 - 4 } & Positive & Negative & $\begin{array}{l}\text { Not performed/ } \\
\text { not reported }\end{array}$ \\
\hline Southeast & $7.7 \%$ & $75.6 \%$ & $16.7 \%$ \\
Northeast & $8.3 \%$ & $51.6 \%$ & $40.1 \%$ \\
South & $8.3 \%$ & $70.4 \%$ & $21.3 \%$ \\
North & $4.2 \%$ & $75.8 \%$ & $20 \%$ \\
Center-West & $5.3 \%$ & $63.5 \%$ & $31.2 \%$ \\
Total & $7.5 \%$ & $67.4 \%$ & $25.1 \%$ \\
\hline
\end{tabular}

Note: Data from Ministry of Health. Health Care Secretary. Coordenação Geral de Sangue e Hemoderivados. Perfil das coagulopatias hereditárias no Brasil: 20II-20I2. [General Coordination of Blood and Blood Products. Profile of hereditary coagulopathies in Brazil: 20II-2012]. Brazil: Ministry of Health; 2014.21 beginning in 2014 and to become the largest manufacturer of blood products in Latin America, to date, all of the FVIII concentrates used in Brazil are still imported. Plasma is collected in Brazilian blood centers and sent to a French laboratory - a technology transfer partner. In France, the plasma is processed and the blood products are sold back to Brazil. ${ }^{26}$

With a limited availability of FVIII concentrate, the treatment of hemophilia A in Brazil was restricted until 2011, to the on-demand format (ie, the infusion of FVIII was performed only after the occurrence of bleeding), making patients travel from their homes to the nearest blood center, upon each episode..$^{27}$ Considering Brazil's territorial dimensions, this travel could be hundreds of kilometers, often on unpaved roads or via river transport. Moreover, given the importance of immediate treatment of bleeding events, ${ }^{28}$ Brazil adopted, in 1999, the "emergency home dose" (Dose Domiciliar de Urgência [DDU]) program. This program selects and trains patients or their caregivers so that they can administer the infusion of a predetermined dose of FVIII concentrate at home immediately at the onset of symptoms, thus delaying, for a few hours, the visit to the blood center. ${ }^{10}$ However, in 2008, a major crisis in supply of FVIII concentrate caused the DDU program to be temporarily suspended in $63 \%$ of the blood centers. ${ }^{29}$

The national average for patients with hemophilia A who have joined the DDU program was 39.3\% in 2012 (Table 6). The states with higher participation in the program were Rio Grande do Sul, with $74.4 \%$ of patients qualified, and Santa Catarina, with $63.5 \%$. The states with lower membership were Amapá, with only 4.7\%; Bahia, with $11.5 \%$; and Rondônia, with $11.7 \%$ participation. There was no information about the DDU membership in the states of Mato Grosso do Sul or Sergipe. ${ }^{21}$

Fearing a new crisis in the FVIII supply in 2011, HEMOBRAS, still under construction, asked the federal government to reconsider import taxes. The temporary suspension of taxes generated a savings estimated at 7.5 million dollars, and a new contract model for the import of blood products was adopted, allowing an increase of $65 \%$ in product purchases. ${ }^{26}$ This increase in availability of FVIII, climbing to 3.7 IU per capita in 2012, was a milestone in the treatment of hemophilia A in Brazil. ${ }^{21}$ Figure 2 shows the per capita consumption of FVIII concentrate in Brazil, in the period 1996-2012., 4, 10,21,30,31

In December 2011, the Ministry of Health approved the guidelines for the primary prophylaxis treatment of boys under 36 months old with severe hemophilia A, following the first hemarthrosis or a severe hemorrhagic event - children gained the right to receive scheduled infusions of FVIII concentrate, one to three times a week, in order to avoid bleeding events and prevent hemophilic arthropathy, the main complication of hemarthrosis. The following month, immune tolerance 
Table 5 Proportion of patients with hemophilia A testing positive for anti-HIV, HBsAg, anti-HCV, and anti-HTLV, Brazil, 2007 and 2012

\begin{tabular}{|c|c|c|c|c|c|c|c|c|}
\hline \multirow[t]{2}{*}{ Serology } & \multicolumn{2}{|c|}{ Anti-HIV } & \multicolumn{2}{|c|}{ HBsAg } & \multicolumn{2}{|c|}{ Anti-HCV } & \multicolumn{2}{|c|}{ Anti-HTLV } \\
\hline & 2007 & 2012 & 2007 & 2012 & 2007 & 2012 & 2007 & 2012 \\
\hline Positive & $4.5 \%$ & $1.4 \%$ & $2.3 \%$ & $1.0 \%$ & $24.2 \%$ & $4.7 \%$ & $0.9 \%$ & $0.1 \%$ \\
\hline Negative & $65.4 \%$ & $15.8 \%$ & $57.9 \%$ & $49.7 \%$ & $45.2 \%$ & $7.7 \%$ & $65.3 \%$ & $8.4 \%$ \\
\hline Not reported or not performed & $30.1 \%$ & $82.8 \%$ & $39.8 \%$ & $49.3 \%$ & $30.6 \%$ & $87.6 \%$ & $33.8 \%$ & $91.5 \%$ \\
\hline
\end{tabular}

Note: Data from Ministry of Health. Health Care Secretary. Departamento de Atenção Especializada. Perfil das coagulopatias hereditárias no Brasil: 2007. [General coordination of blood and blood products. Profile of hereditary coagulopathies in Brazil: 2007]. Brazil: Ministry of Health; $2008 .{ }^{20}$ Ministry of Health. Health Care Secretary. Coordenação Geral de Sangue e Hemoderivados. Perfil das coagulopatias hereditárias no Brasil: 20II-20I2. [General Coordination of Blood and Blood Products. Profile of hereditary coagulopathies in Brazil: 20I I-2012]. Brazil: Ministry of Health; 2014.21

Abbreviations: anti-HCV, hepatitis C antibody; anti-HIV, human immunodeficiency virus antibody; anti-HTLV, anti-human T-lymphotropic antibody; HBsAg, hepatitis B surface antigen.

treatment was authorized for patients with hemophilia A who presented high-response inhibitors. Both of these courses of therapy require high doses of FVIII concentrate. ${ }^{26}$ After 1 year, there were already 140 boys in primary prophylaxis treatment and another 85 patients, including adults and other children (not those in prophylaxis), preexisting inhibitors receiving immune tolerance treatment. ${ }^{21}$

Months later, the Ministry of Health expanded the prophylactic treatment of severe hemophilia to boys over 3 years old and to adults. Prophylaxis initiated at a later stage does not recover the functionality of a joint already affected by hemophilic arthropathy but does reduce the number of bleeding events and prevent sequelae in other joints, thus aiming to improve patients' quality of life. ${ }^{26}$

Meanwhile, in northeastern Brazil, the first phase of the HEMOBRAS factory was inaugurated in September 2012: a fully automated, $350 \mathrm{~m}^{2}$ refrigeration chamber, with a capacity to store one million plasma bags. In that year, the company signed contracts with various Brazilian blood centers to guarantee plasma in sufficient quantity and quality as raw material, and the Ministry of Health guaranteed that construction would continue in order to make Brazil self-sufficient in the production of blood products.

Table 6 Proportion of patients with hemophilia A that participate in the Emergency Home Dose Program, by geographic region, Brazil, 2012

\begin{tabular}{llll}
\hline Region & \multicolumn{3}{l}{$\begin{array}{l}\text { Participation in the emergency home } \\
\text { dose program }\end{array}$} \\
\cline { 2 - 4 } & Yes & No & Not reported \\
\hline Southeast & $32.5 \%$ & $31 \%$ & $36.5 \%$ \\
Northeast & $36.3 \%$ & $21.4 \%$ & $42.3 \%$ \\
South & $57.6 \%$ & $23.0 \%$ & $19.4 \%$ \\
North & $37.8 \%$ & $33.1 \%$ & $29.1 \%$ \\
Center-West & $51.7 \%$ & $20.6 \%$ & $27.7 \%$ \\
Total & $39.3 \%$ & $26.6 \%$ & $34.1 \%$ \\
\hline
\end{tabular}

Note: Data from Ministry of Health. Health Care Secretary. Coordenação Geral de Sangue e Hemoderivados. Perfil das coagulopatias hereditárias no Brasil: 201/-20/2. [General Coordination of Blood and Blood Products. Profile of hereditary coagulopathies in Brazil: 20II-2012]. Brazil: Ministry of Health; 20I4. ${ }^{21}$
However, in March of 2013, the Ministry of Health approved the use of recombinant FVIII concentrate for the treatment of hemophilia A. The drug, produced through genetic engineering, without plasma components, has the advantage of not having to rely on blood donations for its manufacture. A new partnership was established between HEMOBRAS and a private laboratory that would produce the drug. The US-based laboratory agreed to transfer the production technology to Brazilian laboratories over a period of 5 years. In exchange, the government assured exclusivity in its purchase of these products during the same period. ${ }^{26}$

Currently, recombinant FVIII concentrate is gradually replacing plasma-derived concentrate in the treatment of hemophilia A in Brazilian blood centers. However, consumption of FVIII in the Brazilian states is not uniform, ranging from 0.27 IU per capita in the state of Roraima to $7.22 \mathrm{IU}$ per capita in the Federal District. ${ }^{21}$ Although this calculation is influenced by the reported prevalence of hemophilia, when we consider the consumption of FVIII by registered hemophilia A patients, disparities remain. While consumption was slightly over 13,000 IU/patient in the states of Roraima and Mato Grosso do Sul, it had reached over 80,000 international units (IU)/patient in the Federal District in 2012, even though the latter two federal units belong to the same geographical region. Figure 3 shows the average FVIII consumption per patient with hemophilia A in the Brazilian states.

\section{Comprehensive health care and hemophilia A in Brazil}

Guaranteeing hemophilia patients access to health promotion, protection, and recovery actions, as advocated by the SUS, requires more than just the availability of FVIII concentrate. Among the 183 existing HTCs in Brazil, there are services truly specialized in providing multidisciplinary treatment, with professionals from various areas who are trained to provide comprehensive care to the patient. This approach 


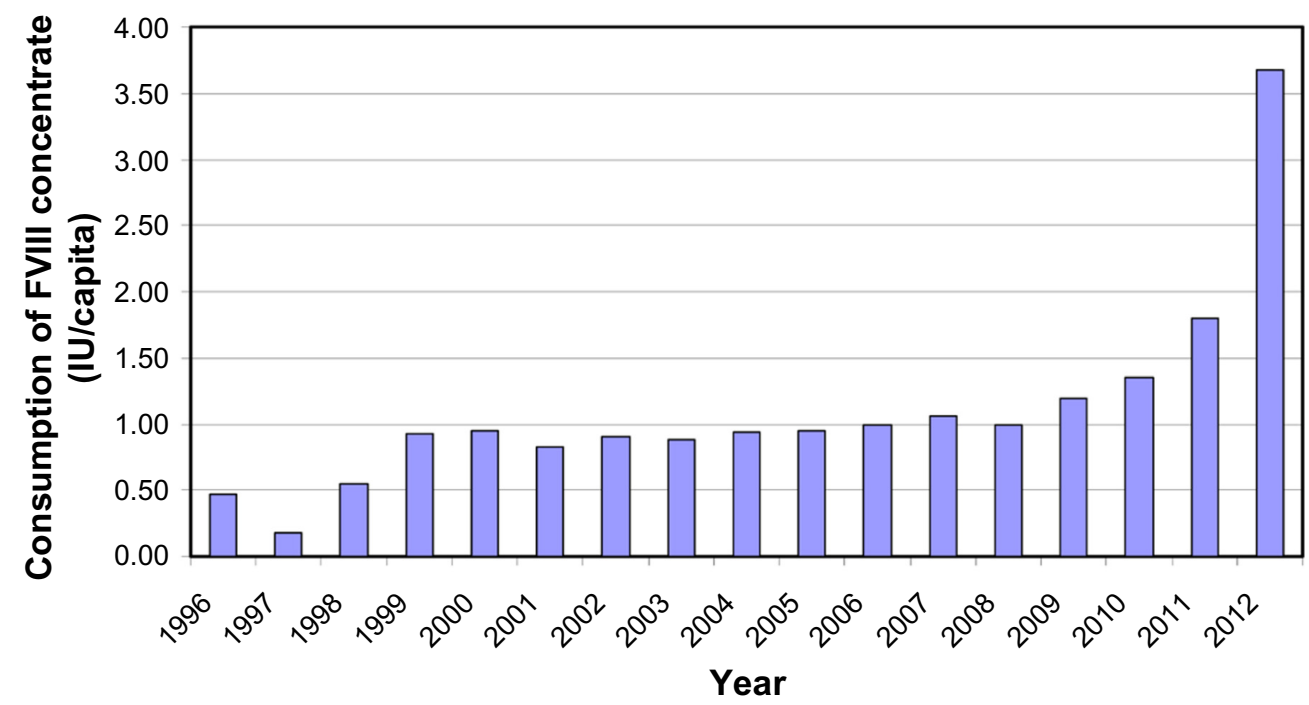

Figure 2 Consumption of FVIII concentrate in IU per capita in Brazil, 1996-2012.4,10,21,30,31

Abbreviation: FVIII, factor VIII.

has already been suggested to be capable of reducing the mortality of patients with hemophilia. ${ }^{32}$

Most HTCs are situated in blood centers or university hospitals. Some have teams including hematologists, orthopedists, physiatrists, infectious disease specialists, nurses, dentists, physiotherapists, psychologists, and social workers. Other HTCs are mere dispensaries for FVIII concentrate and do not offer clinical care.

Currently, in this country, 120 hemotherapy services linked to the public health network provide outpatient care for patients with hemophilia. Of this total, 52 (43.3\%) are distributed in only three states, with 27 in Minas Gerais, 14 in São Paulo, and eleven in Rio Grande do Sul. However, in nine of the 27 Brazilian states, attention remains restricted to a single HTC, located in the state capital, as shown in Figure 4. ${ }^{33}$

In 2007, a survey showed that more than half of the patients had difficulty getting access to a hematologist and $31 \%$, to psychological care. Over $30 \%$ reported not having access to physiotherapy followup,,$^{34}$ even though physiotherapy is considered essential for the treatment and rehabilitation of patients with hemophilia. ${ }^{35}$

With regard to the prevention and treatment of infectious diseases potentially transmissible by blood components and blood products, the SUS offers vaccines against hepatitis

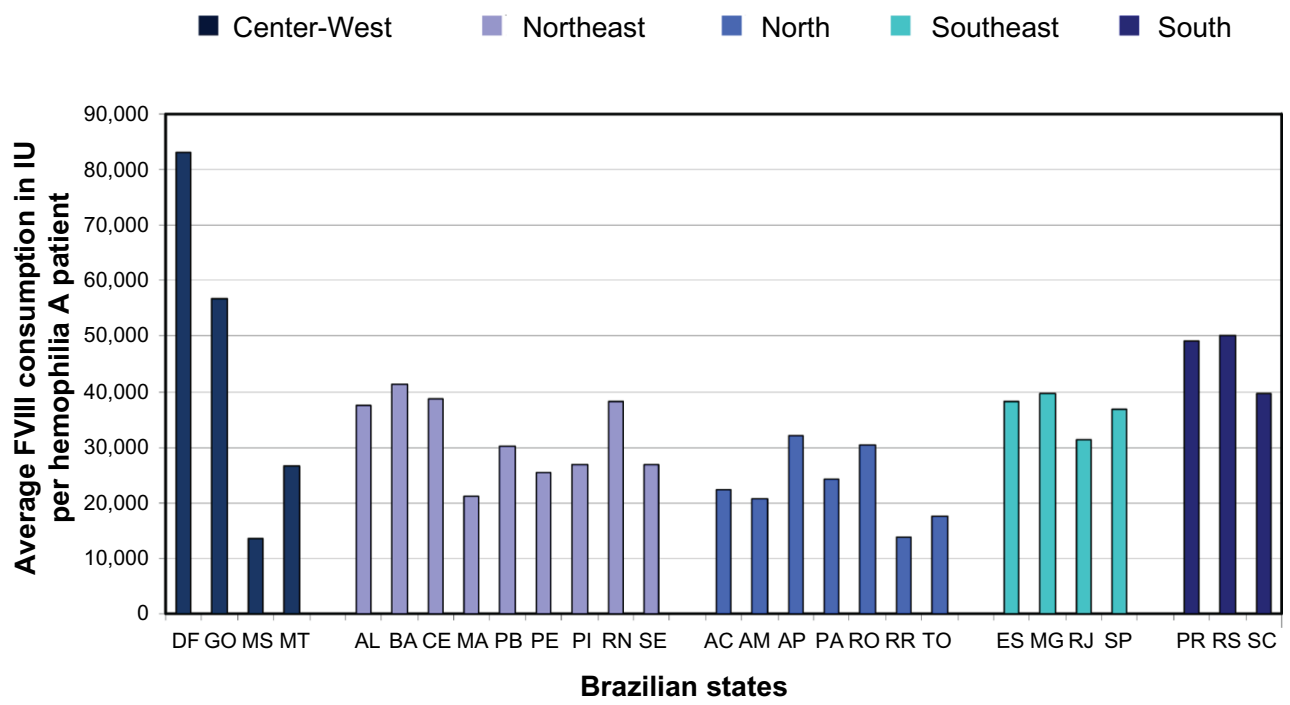

Figure 3 Average FVIII consumption in IU, per hemophilia A patient, by Brazilian state, 2012 .

Note: Data from Ministry of Health. Health Care Secretary. Coordenação Geral de Sangue e Hemoderivados. Perfil das coagulopatias hereditárias no Brasil: 201 I-20I2. [General Coordination of Blood and Blood Products. Profile of hereditary coagulopathies in Brazil: 20I I-20I2]. Brazil: Ministry of Health; 20I4. ${ }^{21}$

Abbreviations: FVIII, factor VIII; AC, Acre; AL, Alagoas; AM, Amazonas; AP, Amapá; BA, Bahia; CE, ; DF, Federal District; ES, Espírito Santo; GO, Goiás; MA, Maranhão; MG, Minas Gerais; MS, Grosso do Sul; Mato Grosso; PA, Pará; PB, Paraíba; PE, Pernambuco; PI, Piauí; PR, Paraná; RJ, Rio de Janeiro; RN, Rio Grande do Norte; RO, Rondônia; RR, Roraima; RS, Rio Grande do Sul; SC, Santa Catarina; SE, Sergipe; SP, São Paulo; TO, Tocantins. 


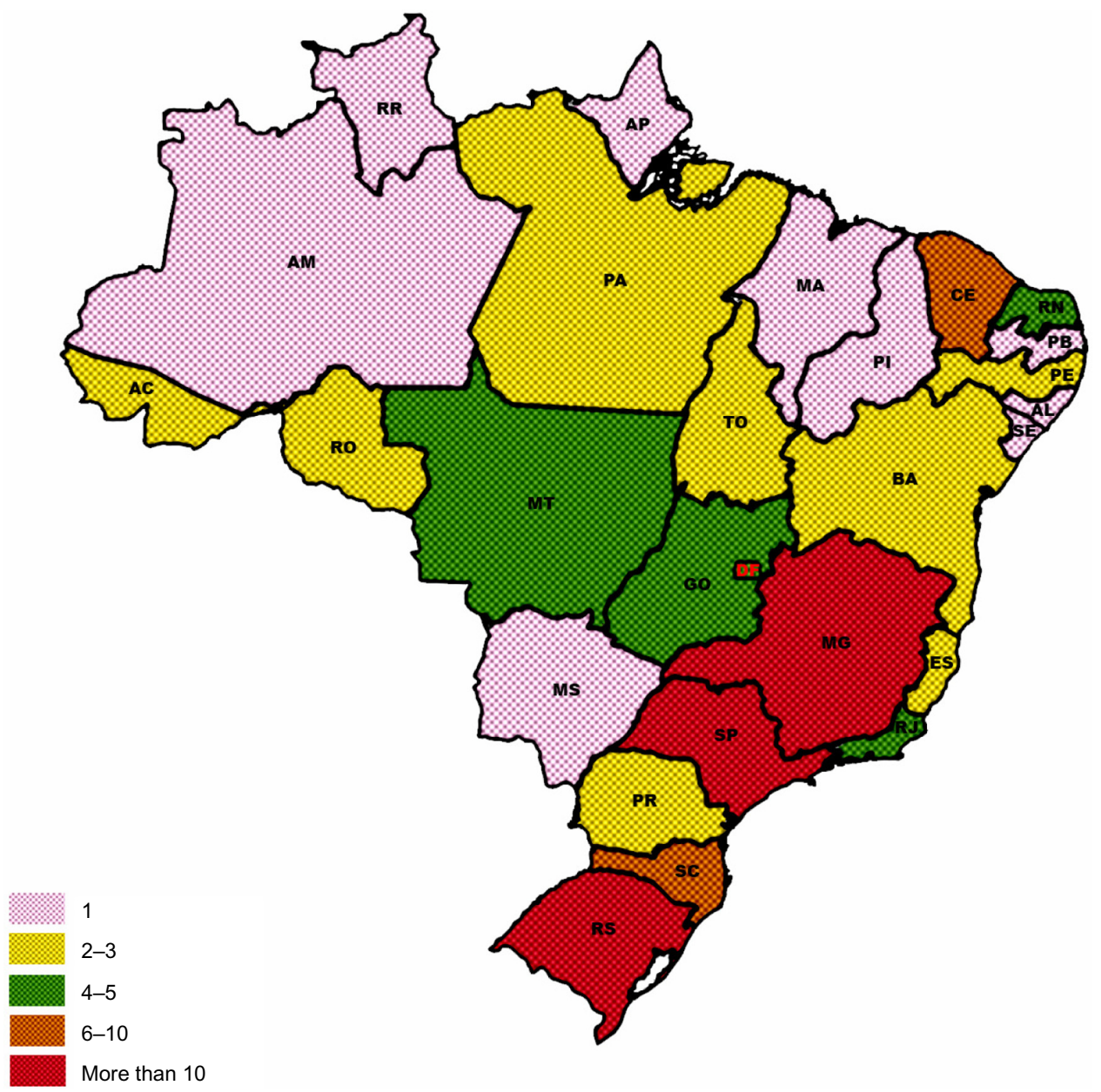

Figure 4 Distribution of the hemotherapy services linked to the public health network that provides outpatient care to patients with hemophilia, by state, Brazil, $2014 .^{33}$ Abbreviations: AC, Acre; AL, Alagoas; AM, Amazonas; AP, Amapá; BA, Bahia; CE, ; DF, Federal District; ES, Espírito Santo; GO, Goiás; MA, Maranhão; MG, Minas Gerais; MS, Grosso do Sul; Mato Grosso; PA, Pará; PB, Paraíba; PE, Pernambuco; PI, Piauí; PR, Paraná; RJ, Rio de Janeiro; RN, Rio Grande do Norte; RO, Rondônia; RR, Roraima; RS, Rio Grande do Sul; SC, Santa Catarina; SE, Sergipe; SP, São Paulo; TO, Tocantins.

types $\mathrm{A}$ and $\mathrm{B}$, as well as treatment for hepatitis types $\mathrm{B}$ and $\mathrm{C} .{ }^{36}$ The Brazilian policy of confronting acquired immunodeficiency syndrome (AIDS) assures infected patients free and quality antiretroviral treatment. The program has wide coverage and has been touted as a model for other countries, although it receives criticism for failing to reduce the incidence of the disease in this country. ${ }^{37}$

\section{Conclusion}

After the ban on the sale of blood and blood products in 1998, a milestone in the treatment of hemophilia A in Brazil was the implementation of prophylaxis treatment in 2011. While the SUS ensures the availability of FVIII concentrate, there is much to be sought to ensure comprehensive health care attention to patients with hemophilia. Improvements are needed in all stages of care: from access to early diagnosis, to access to multidisciplinary treatment, as well as rehabilitation and social inclusion of individuals with joint sequelae or chronic infectious diseases. The fragility of the inherited bleeding disorders information system is evident. The HTC difficulties in maintaining current data hinders the Ministry of Health's recognition of adjustments to the national program that are needed to reduce regional inequalities in the treatment of hemophilia. Finally, for patients included in the prophylaxis program, there is essential need to develop tools to assess the effectiveness of this therapeutic modality in the Brazilian context.

\section{Disclosure}

The authors report no conflicts of interest in this work.

\section{References}

1. Friedman KD, Rodgers GM. Inherited coagulation disorders. In: Greer JP, Foerster J, Rodgers GM, et al, editors. Wintrobe's Clinical Hematology, Vol 2. 12th ed. Philadelphia, PA: Lippincott Williams \& Wilkins; 2009:1379-1424.

2. Mannucci PM, Tuddenham EG. The hemophilias - from royal genes to gene therapy. N Engl J Med. 2001;344(23):1773-1779. 
3. Pergantou H, Platokouki H, Matsinos G, et al. Assessment of the progression of haemophilic arthropathy in children. Haemophilia. 2010;16(1):124-129.

4. Ministry of Health. Health Care Secretary. Coordenação Geral de Sangue e Hemoderivados. Perfil das coagulopatias hereditárias no Brasil: 2009-2010. [General coordination of blood and blood products. Profile of hereditary coagulopathies in Brazil: 2009-2010]. Brazil: Ministry of Health; 2012. Portuguese.

5. ibge.gov.br [homepage on the Internet]. Área territorial Brasileira Instituto Brasileiro de Geografia e Estatística [cited May 8, 2014]. Available from: http://ibge.gov.br/home/geociencias/cartografia/ default_territ_area.shtm. Accessed May 8, 2014. Portuguese.

6. Brazilian Institute of Geography and Statistics - IBGE. Directorate of Surveys, Department of Population and Social Indicators. Sintese de Indicadores Sociais 2013. Uma análise das Condições de Vida da População Brasileira. [A syntheses of social indicators 2013]. Brazil: Brazilian Institute of Geography and Statistics; 2013. Available from: http://www. ibge.gov.br/home/presidencia/noticias/imprensa/ppts/000000154717111 02013171529343967.pdf. Accessed February 27, 2014. Portuguese.

7. databank.worldbank.org [homepage on the Internet]. World development indicators: Brazil, 2012. The World Bank; 2014 [updated July 1, 2014; cited February 27, 2014]. Available from: http://data.worldbank.org/ indicator/SI.POV.GINI/countries/1W-BR?display=graph. Accessed July 21, 2014.

8. conselho.saude.gov.br [homepage on the Internet]. O SUS. [The unique health system - SUS]. Ministry of Health. National Council of Health; 2008 [cited February 27, 2014]. Available from: http://conselho.saude. gov.br/web_sus20anos/sus.html. Accessed July 21, 2014. Portuguese.

9. Rezende SM, Pinheiro K, Caram C, Genovez G, Barca D. Registry of inherited coagulopathies in Brazil: first report. Haemophilia. 2009;15(1):142-149.

10. Antunes SV. Haemophilia in the developing world: the Brazilian experience. Haemophilia. 2002;8(3):199-204.

11. hemominas.mg.gov.br [homepage on the Internet]. Sangue: breve história. [Blood: a brief history]. Foundation and Center for Hematology and Hemotherapy of Minas Gerais (HEMOMINAS) [updated November 21, 2011; cited March 8, 2014]. Available from: http://www.hemominas.mg.gov.br/hemominas/menu/cidadao/doacao/breve_historia.html. Accessed July 21, 2014. Portuguese.

12. Portaria Interministerial n.7, de 30 de abril de 1980. Aprova as diretrizes básicas do Programa Nacional de Sangue e Hemoderivados (Pró-Sangue). [Ministerial Decree n.7, Apr 30, 1980. Approval of basic guidelines of the National Program of Blood and Blood Products (Pró-Sangue)]. Diário Oficial da União, Brasília. 1980;1:8226. Portuguese.

13. Fontes EM, Amorim L, Carvalho SM, Farah MB. Hemophilia care in the state of Rio de Janeiro, Brazil. Rev Panam Salud Publica. 2003; 13(2-3):124-128.

14. World Federation of Hemophilia. World Federation of Hemophilia Report on the Annual Global Survey 2008. Montreal, QC: World Federation of Hemophilia; 2009.

15. Brazilian Health Surveillance Agency (ANVISA). Gerência Geral de Sangue e Hemoderivados. Relatório Estatístico de 2000: Fatores de Coagulação. [General coordination of blood and blood products. Statistical report 2000: coagulation factors]. Brazil; ANVISA; 2001. Portuguese.

16. Resolução da Diretoria Colegiada n.23, de 25 de janeiro de 2002. Aprova o Regulamento Técnico sobre a indicação de uso de crioprecipitado. [Executive Board Resolution. Approval of technical regulations for use of cryoprecipitate]. Diário Oficial da União, Brasília. 2002;1:25. Portuguese.

17. Evatt B. World Federation of Hemophilia Guide to Developing a National Patient Registry. Montreal, QC: World Federation of Hemophilia; 2005

18. Ragni M. Hemorrhagic disorders: coagulation factor deficiencies. In: Goldman L, Schafer AI, editors. Goldman's Cecil Medicine. 24th ed. Philadelphia, PA: Elsevier Saunders; 2012:1137-1145.
19. Stonebraker JS, Bolton-Maggs PH, Soucie JM, Walker I, Brooker M. A study of variations in the reported haemophilia A prevalence around the world. Haemophilia. 2010;16(1):20-32.

20. Ministry of Health. Health Care Secretary. Departamento de Atenção Especializada. Perfil das coagulopatias hereditárias no Brasil: 2007. [General coordination of blood and blood products. Profile of hereditary coagulopathies in Brazil: 2007]. Brazil: Ministry of Health; 2008. Portuguese.

21. Ministry of Health. Health Care Secretary. Coordenação Geral de Sangue e Hemoderivados. Perfil das coagulopatias hereditárias no Brasil: 2011-2012. [General Coordination of Blood and Blood Products. Profile of hereditary coagulopathies in Brazil: 2011-2012]. Brazil: Ministry of Health; 2014. Portuguese.

22. ibge.gov.br [homepage on the Internet]. Censo demográfico 2010. Instituto Brasileiro de Geografia e Estatítica; 2010 [Census 2010. Brazilian Institute of Geography and Statistics - IBGE]. [cited February 27, 2014]. Available from: http://www.ibge.gov.br/home/ estatistica/populacao/censo2010/default.shtm. Accessed July 21, 2014. Portuguese.

23. Ragni MV, Kessler CM, Lozier JN. Clinical aspects and therapy of hemophilia. In: Hoffman R, Benz EJ Jr, Shatill SJ, et al, editors. Hematology: Basics Principles and Practice. 5th ed. Philadelphia, PA: Elsevier Churchill Livingstone; 2009:1911-1930.

24. Ministry of Health. Health Care Secretary. Specialized Care Department. Hemofilia Congênita e Inibidor: Manual de Diagnóstico e Tratamento de Eventos Hemorrágicos. [Congenital hemophilia and inhibitor: handbook of diagnosis and treatment of hemorrhagic events]. Brazil: Ministry of Health; 2008. Portuguese.

25. Ferreira AA, Leite IC, Bustamante-Teixeira MT, et al. Health-related quality of life in hemophilia: results of the Hemophilia-Specific Quality of Life Index (Haem-a-Qol) at a Brazilian blood center. Rev Bras Hematol Hemoter. 2013;35(5):314-318.

26. Portal Brasil: resultado da busca por hemofilia. [homepage on the Internet]. Notícias sobre hemophilia. [Search result for hemophilia]. Portal Brasil; 2013 [updated July 3, 2014; cited March 8, 2014]. Available from: http://www.brasil.gov.br/@@busca?SearchableText=hemofilia. Accessed July 21, 2014. Portuguese.

27. Villaça PR, Carneiro JDA, D’Amico EA. Hemofilias. In: Zago MA, Falcão RP, Pasquini R. Hematologia: Fundamentos e Prática. [Hematology: fundamentals and practice] São Paulo: Atheneu; 2001: 803-817. Portuguese.

28. Gilbert MS. Musculoskeletal complications of haemophilia: the joint. Haemophilia. 2000;6 Suppl 1:S34-S37.

29. Lima JJV. Ação Atenção aos Pacientes Portadores de Coagulopatias: Relatório de Auditoria Operacional. [Action care to patients with coagulopathies: performance audit report]. Brazil: Brazilian Federal Court of Accounts; 2011. Portuguese.

30. Ministry of Health. Caderno de Informação: Sangue e Hemoderivados. Rede Física, Produção, Gastos Públicos com Hemoterapia e Consumo de Hemoderivados. [Information Notebook: blood and hemoderivates: physical network, output, public expenses with hemotherapy and hemoderivates consumption]. Brazil: Ministry of Health; 2007.

31. Stonebraker JS, Brooker M, Amand RE, Farrugia A, Srivastava A. A study of reported factor VIII use around the world. Haemophilia. 2010;16(1):33-46.

32. Soucie JM, Nuss R, Evatt B, et al. Mortality among males with hemophilia: relations with source of medical care. The Hemophilia Surveillance System Project Investigators. Blood. 2000;96(2):437-442.

33. 1.anvisa.gov.br [homepage on the Internet]. HEMOCAD. [Database Blood and Blood Products. Hemotherapy services; 2000]. Brazilian Health Surveillance Agency (ANVISA); 2000 [cited April, 3, 2014]. Available from: http://www1.anvisa.gov.br/anvisa/hemocad/RelatorioUHMultiParametros.jsp. Accessed: August 13, 2014. Portuguese.

34. Vilaça MV. Ação Atenção aos Pacientes Portadores de Coagulopatias: Relatório de Auditoria Operacional. [Action care to patients with coagulopathies: performance audit report]. Brazil: Brazilian Federal Court of Accounts; 2007. Portuguese. 
35. Beeton K, Padkin J. Physiotherapy in the management of hemophilia. In: Lee CA, Berntop EE, Hoots WK, editors. Textbook of Hemophilia. 2nd ed. Oxford: Wiley Blackwell; 2010:200-205.

36. Ministry of Health. Secretary of Health Surveillance. Department of Epidemiological Surveillance. Manual de Aconselhamento em Hepatites Virais. [Advisement Manual of Viral Hepatitis]. Brazil: Ministry of Health; 2005.
37. aids.gov.br [homepage on the Internet]. Política Brasileira de enfrentamento da Aids - 2012. [Brazilian Policy on Addressing AIDS - 2012]. Brazil: Ministry of Health. Department of STD, AIDS, and Viral Hepatitis; 2012 [updated March 19, 2013; cited March 14, 2014]. Available from: http://www.aids.gov.br/publicacao/2013/politicabrasileira-de-enfrentamento-da-aids-2012. Accessed July 21, 2014. Portuguese.

Journal of Blood Medicine

\section{Publish your work in this journal}

The Journal of Blood Medicine is an international, peer-reviewed, open access, online journal publishing laboratory, experimental and clinical aspects of all topics pertaining to blood based medicine including but not limited to: Transfusion Medicine; Blood collection, Donor issues, Transmittable diseases, and Blood banking logistics; Immunohematology; Artificial and alternative

\section{Dovepress}

blood based therapeutics; Hematology; Biotechnology/nanotechnology of blood related medicine; Legal aspects of blood medicine; Historical perspectives. The manuscript management system is completely online and includes a very quick and fair peer-review system. Visit http://www.dovepress.com/ testimonials.php to read real quotes from published authors.

Submit your manuscript here: http://www.dovepress.com/Journal-of-blood-medicine-journal 